\title{
Feeding of Calanus helgolandicus on Phytoplankton Mixtures
}

\author{
S. B. Schnack \\ Institut für Meereskunde an der Universität Kiel, Düsternbrooker Weg 20, D-2300 Kiel 1, Federal Republic of Germany
}

ABSTRACT: In order to examine feeding selectivity by copepods, females of Calanus helgolandicus were allowed to graze on a mixture of three different chain-forming diatoms: Thalassiosira rotula $(40 \times 15 \mu \mathrm{m})$, Chaetoceros pseudocurvisetus ( $\varnothing 15 \mu \mathrm{n})$ and Stephanopyxis palmeriana $(85 \times 45 \mu \mathrm{m})$. T. rotula was deliberately offered at higher abundancies. C. helgolandicus filter a higher rate of $C$. pseudocurvisetus than of $S$. palmeriana and $T$. rotula, and graze preferentially on this spiny form. During experiments, $T$ rotula rarely decrease, and electivity regarding this species was always negative; in contrast, on $S$. palmeriana and $C$. pseudocurvisetus it was always positive. Net particle production occurred only in the smaller chains $(2,3$ and 4 cells per chain) of S. palmeriana; net particle removal was recorded on all phytoplankton species, but in $S$. palmeriana only on single cells and longer chains. Within a given species, removal pressure was high on large chains of $S$. palmeriana and $T$. rotula, whereas in C. pseudocurvisetus a greater variability prevailed. Maximum removal occurred at or near modal peaks.

\section{INTRODUCTION}

Since Harvey's (1937) report on size-selective feeding by copepods, a great number of papers have been published on this theme. For reviews consult 'Marine Ecology', Volume III: Kinne, 1977, and Volume IV: Conover, 1978. Although there is general agreement that copepods do indeed feed selectively, experimental results are frequently contradictory with regard to actual feeding behaviour. Selective feeding is evidently regulated by a large number of factors such as quality and quantity of available food and previous feeding history of the copepods.

In the present study grazing experiments were conducted using three chain-forming diatoms as food. While Thalassiosira rotula is known as a good food source for Calanus species (Paffenhöfer, 1976, Schnack, 1978), Stephanopyxis palmeriana is a relati-

Table 1. Mean size and estimated cell volume of diatom species used in feeding experiments. The species were isolated and cultured from the NW-African upwelling area by H. K. Schöne

\begin{tabular}{|lccc|}
\hline Phytoplankton species & $\begin{array}{c}\text { Mean cell } \\
\text { size }(\mu \mathrm{m})\end{array}$ & $\begin{array}{l}\text { Mean cell } \\
\text { vol. }\left(\mu \mathrm{m}^{3}\right)\end{array}$ \\
\hline Chaetoceros pseudocurvisetus & $\varnothing$ & 15 & 2200 \\
Thalassiosira rotula & $40 \times 15$ & 13000 \\
Stephanopyxis palmeriana & $85 \times 45$ & 136000 \\
\hline
\end{tabular}

vely poor one (Schnack, 1978). Contrasting results were obtained with spiny Chaetoceros species as food for copepods (e. g. Harvey, 1937, Marshall and Orr, 1955). The question addressed here is: How do Calanus helgolandicus females behave in a mixture of these three different diatoms, when the most suitable food organism (T. rotula) is much more abundant than the two other species?

\section{MATERIAL AND METHODS}

Selective feeding experiments were carried out with adult female Calanus helgolandicus in December 1977. The copepods used in the experiments were collected in the North Sea. 25 healthy females were placed in each of four 4-1 beakers containing 31 of a suspension of algal mixture. One control beaker was used containing identical algal cultures but no copepods. The contents of the beakers were kept homogeneous by using Plexiglas stirrers rotating at 2 rpm (Frost, 1972). The copepods were conditioned for one day before experimentation began. The experiments were conducted in dim light at a temperature of $15^{\circ} \mathrm{C}$ for $15 \mathrm{~h}$. Food concentrations were measured by counting 5-10 subsamples of $50 \mathrm{ml}$ each under an inverted microscope. Three chain-forming diatom species were used in the experiments. The phytoplankton was cultured at $15^{\circ} \mathrm{C}$ before experimentation. Average cell volumes were estimated after Smetacek (1975). 
Table 2. Filtration rates of female Calanus helgolandicus Mono-algal diet

\begin{tabular}{lcc} 
Phytoplankton species & $\begin{array}{c}\text { Mean particle } \\
\text { conc. }\left(\mu \mathrm{m}^{3} \mathrm{ml}^{-1}\right)\end{array}$ & $\begin{array}{c}\text { Filtration rates } \\
\left(\mathrm{ml} \mathrm{cop}^{-1} \mathrm{~h}^{-1}\right)\end{array}$ \\
\hline Chaetoceros & $59 \times 10^{4}$ & 6.39 \\
pseudocurvisetus & $72 \times 10^{4}$ & 6.17 \\
& $60 \times 10^{4}$ & 5.03 \\
Thalassiosira rotula & $62 \times 10^{4}$ & 5.96 \\
& $88 \times 10^{4}$ & 4.62 \\
& $90 \times 10^{4}$ & 5.89 \\
Stephanopyxis & $97 \times 10^{4}$ & 6.31 \\
palmeriana & $88 \times 10^{4}$ & 5.46 \\
& $62 \times 10^{4}$ & 5.60 \\
& $87 \times 10^{4}$ & 5.26 \\
& $77 \times 10^{4}$ & 5.44 \\
$71 \times 10^{4}$ & 4.87
\end{tabular}
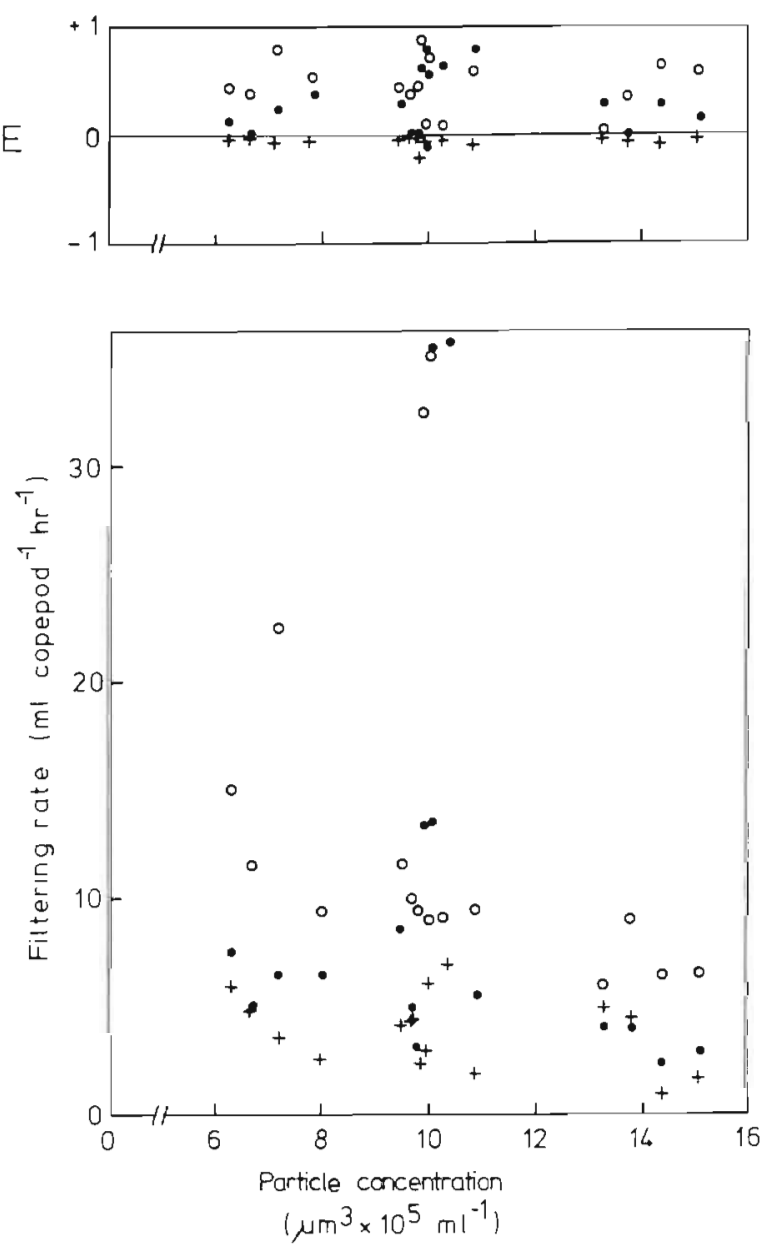

Fig. 1 Filtration rates and food electivity plotted against mean total particle concentration available (all three species combined). o Chaetoceros pseudocurvisetus; + Thalassiosira rotula; • Stephanopyxis palmeriana
The size of the chains varied over a broad range depending on the number of cells per chain. The mean size and volume of the cells are presented in Table 1. Filtration rates on each species were calculated after the formula given by Gauld (1951). Selection was
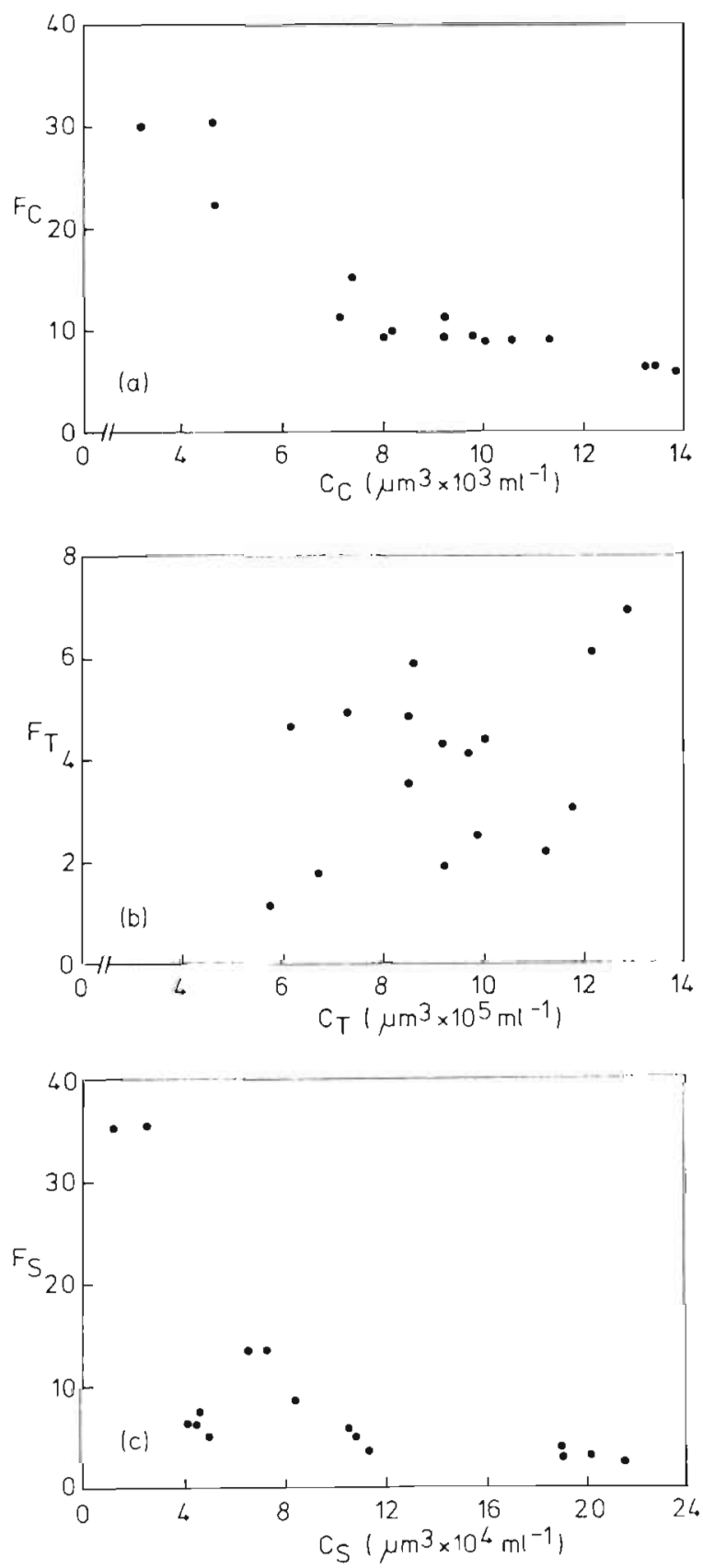

Fig. 2. Filtration rates of Chaetoceros pseudocurvisetus (a), Thalassiosira rotula (b) and Stephanopyxis palmeriana (c) versus concentration of the respective species. $C_{C}$ : Concentration of $C$ pseudocurvisetus; $C_{S}$ : Concentration of $S$. palmeriana: $\mathrm{C}_{\mathrm{T}}$ : Concentration of $T$ rotula; $\mathrm{F}_{\mathrm{C}}$ : Filtration rate $(\mathrm{ml}$ copepod ${ }^{-1} \mathrm{~h}^{-1}$ ) of $C$. pseudocurvisetus; $\mathrm{F}_{\mathrm{s}}$ : Filtration rate (ml copepod ${ }^{-1} \mathrm{~h}^{-1}$ ) of $S$ palmeriana; $\mathrm{F}_{\mathrm{T}}$; Filtration rate (ml copepod ${ }^{-1} \mathrm{~h}^{-1} \mathrm{j}$ of $T$ rotula 
quantified by means of Ivlev's (1961) electivity index: $E=\left(r_{i}-p_{i}\right) /\left(r_{i}+p_{i}\right)$, where $r_{i}$ is the relative proportion of one phytoplankton species in the ration and $p$, the relative proportion of the same phytoplankton species in the total available food particles.

\section{RESULTS}

No great difference was found between filtration rates of Calanus helgolandicus when feeding on monospecific cultures of the three phytoplankton species

Table 3. Summary of Calanus helgolandicus grazing experiments. C: Chaetoceros pseudocurvisetus, T Thalassiosira rotula, S : Stephanopyxis palmeriana

\begin{tabular}{|c|c|c|c|c|c|c|c|c|}
\hline \multirow{2}{*}{$\begin{array}{c}\text { Food } \\
\text { organism }\end{array}$} & \multirow{2}{*}{$\begin{array}{c}\text { Mean } \\
\text { food conc. } \\
\left(\mu \mathrm{m}^{3} \mathrm{ml}^{-1}\right)\end{array}$} & \multirow{2}{*}{$\begin{array}{c}\text { Percent } \\
\text { avail. }\end{array}$} & \multirow{2}{*}{$\begin{array}{c}F \\
(\text { ml cop } \\
\left.\operatorname{cop}^{-1} h^{-1}\right)\end{array}$} & \multirow{2}{*}{$\begin{array}{c}\mathrm{I} \\
\left(\mu \mathrm{m}^{3} \times 10^{3} /\right. \\
\left.\text { eaten } \operatorname{cop}^{-1} \mathrm{~h}^{-1}\right)\end{array}$} & \multirow{2}{*}{$\begin{array}{c}\text { Percent } \\
\text { eaten }\end{array}$} & \multicolumn{3}{|c|}{ Electivity ( $E$ ) } \\
\hline & & & & & & $\mathrm{C}$ & $\mathrm{T}$ & S \\
\hline $\mathrm{C}$ & 2664 & 0.3 & 30.5 & 141 & 4.6 & & & \\
\hline $\mathrm{T}$ & 920010 & 93.2 & 2.2 & 1989 & 64.5 & +0.89 & -0.18 & +0.65 \\
\hline $\mathrm{S}$ & 65008 & 6.6 & 13.2 & 952 & 30.9 & & & \\
\hline $\mathrm{C}$ & 9963 & 1.0 & 9.0 & 95 & 1.3 & & & \\
\hline $\mathrm{T}$ & 972790 & 97.8 & 6.1 & 6084 & 87.0 & +0.09 & -0.12 & +0.78 \\
\hline $\mathrm{S}$ & 12376 & 1.2 & 35.3 & 816 & 11.7 & & & \\
\hline $\mathrm{C}$ & 4600 & 0.5 & 30.5 & 141 & 3.7 & & & \\
\hline $\mathrm{T}$ & 922701 & 92.3 & 3.0 & 2769 & 71.7 & +0.78 & -0.13 & +0.55 \\
\hline $\mathrm{S}$ & 72488 & 7.2 & 13.6 & 952 & 24.6 & & & \\
\hline $\mathrm{C}$ & 10494 & 1.0 & 9.0 & 94 & 1.2 & & & \\
\hline $\mathrm{T}$ & 996281 & 96.6 & 6.9 & 6877 & 86.8 & +0.08 & -0.05 & +0.66 \\
\hline $\mathrm{S}$ & 25024 & 2.4 & 35.6 & 953 & 12.0 & & & \\
\hline $\mathrm{C}$ & 9207 & 0.8 & 9.4 & 79 & 3.2 & & & \\
\hline $\mathrm{T}$ & 985621 & 90.3 & 1.9 & 1885 & 75.2 & +0.58 & -0.09 & +0.79 \\
\hline $\mathrm{S}$ & 96288 & 8.8 & 5.3 & 544 & 21.6 & & & \\
\hline $\mathrm{C}$ & 7099 & 0.8 & 11.4 & 88 & 2.0 & & & \\
\hline $\mathrm{T}$ & 857285 & 90.3 & 4.1 & 3536 & 82.2 & +0.46 & -0.05 & +0.28 \\
\hline $\mathrm{S}$ & 84864 & 8.9 & 8.4 & 680 & 15.8 & & & \\
\hline C & 8010 & 0.8 & 9.3 & 79 & 2.3 & & & \\
\hline $\mathrm{T}$ & 854880 & 87.6 & 4.3 & 3005 & 86.0 & +0.47 & -0.00 & +0.00 \\
\hline $\mathrm{S}$ & 113288 & 11.6 & 3.4 & 408 & 11.7 & & & \\
\hline C & 8096 & 0.8 & 9.9 & 86 & 2.0 & & & \\
\hline$T$ & 849537 & 88.0 & 4.4 & 3757 & 85.6 & +0.40 & -0.01 & +0.05 \\
\hline $\mathrm{S}$ & 108120 & 11.2 & 4.8 & 544 & 12.4 & & & \\
\hline $\mathrm{C}$ & 9786 & 1.3 & 9.5 & 99 & 4.5 & & & \\
\hline $\mathrm{T}$ & 733577 & 93.3 & 2.5 & 1820 & 83.1 & +0.57 & -0.06 & +0.39 \\
\hline $\mathrm{S}$ & 42568 & 5.4 & 6.5 & 272 & 12.4 & & & \\
\hline C & 7430 & 1.5 & 15.1 & 130 & 3.2 & & & \\
\hline $\mathrm{T}$ & 581711 & 91.3 & 5.9 & 3523 & 86.8 & +0.46 & -0.03 & +0.17 \\
\hline $\mathrm{S}$ & 45424 & 7.2 & 7.4 & 406 & 10.0 & & & \\
\hline C & 9214 & 1.4 & 11.3 & 112 & 3.3 & & & \\
\hline $\mathrm{T}$ & 614458 & 91.2 & 4.8 & 3029 & 88.7 & +0.41 & -0.01 & +0.03 \\
\hline $\mathrm{S}$ & 50320 & 7.4 & 5.0 & 272 & 8.0 & & & \\
\hline C & 4567 & 0.6 & 22.5 & 141 & 5.2 & & & \\
\hline$T$ & 668356 & 93.4 & 3.5 & 2327 & 84.9 & +0.78 & -0.05 & +0.25 \\
\hline $\mathrm{S}$ & 42432 & 5.9 & 6.5 & 271 & 9.9 & & & \\
\hline C & 13812 & 1.0 & 6.0 & 84 & 1.1 & & & \\
\hline $\mathrm{T}$ & 1123551 & 84.7 & 4.8 & 5525 & 73.5 & +0.04 & -0.07 & +0.28 \\
\hline$\hat{\mathrm{S}}$ & 189448 & 14.3 & 4.1 & 1904 & 25.4 & & & \\
\hline $\mathrm{C}$ & 13350 & 0.9 & 6.5 & 88 & 4.4 & & & \\
\hline $\mathrm{T}$ & 1215006 & 84.2 & 1.1 & 1391 & 68.8 & +0.65 & -0.10 & +0.29 \\
\hline $\mathrm{S}$ & 215560 & 14.9 & 2.3 & 544 & 26.8 & & & \\
\hline $\mathrm{C}$ & 11198 & 0.8 & 9.0 & 106 & 1.7 & & & \\
\hline $\mathrm{T}$ & 1175369 & 85.4 & 4.6 & 5400 & 84.6 & +0.34 & -0.01 & +0.00 \\
\hline $\mathrm{S}$ & 189448 & 13.8 & 3.9 & 880 & 13.7 & & & \\
\hline $\mathrm{C}$ & 13171 & 0.9 & 6.6 & 88 & 3.2 & & & \\
\hline $\mathrm{T}$ & 1288456 & 85.3 & 1.7 & 2158 & 77.3 & +0.57 & -0.05 & +0.17 \\
\hline S & 208896 & 13.8 & 2.8 & 544 & 19.5 & & & \\
\hline
\end{tabular}


(Table 2). In feeding experiments using a mixture of all three species, Thalassiosira rotula was most abundant. More than $90 \%$ of the total available cells and more than $80 \%$ of the available cell volume were represented by this species. The relative frequency of the species was the same in all experiments (Table 3). With two exceptions $C$. helgolandicus filtered at the highest rate on Chaetoceros pseudocurvisetus. Usually higher filtration rates were found on Stephanopyxis palmeriana than on $T$. rotula (Table 3 ). There are significant differences in filtration rates: between $C$. pseudocurvisetus and $T$. rotula at the $1 \%$ level and between C. pseudocurvisetus and $S$. palmeriana at the $5 \%$ level (Wilcoxon and Wilcox test for multiple comparison). The filtration rates on $T$. rotula and $S$. palmeriana were not related either to the total available particle concentration (Fig. 1) or to the density of the respective species (Fig. 2). The filtration rate on $C$. pseudocurvisetus was also independent of the total concentration (Fig. 1), but not of the density of Chaetoceros cells (Fig. 2). The electivity on the most abundant species, $T$. rotula was always negative but close to zero, but on C. pseudocurvisetus and $S$. palmeriana it was always positive (Table 3 ). For all species the electivity was independent of total abundance of food (Fig. 1).

The chain-length frequency for the three species at the beginning and end of one experiment is shown in Fig. 3; the variance between beakers and experiments was below $3 \%$.

Only in Stephanopyxis palmeriana were the chains much shorter at the end than at the beginning. When plotting the differences between chain-length frequencies in 'grazing beakers' (with copepods) and control beakers (without copepods) against the number of cells per chain, the resulting curves are below zero in Thalassiosira rotula and Chaetoceros pseudocurvisetus (Fig. 4). In S. palmeriana however, there is an increase in short chains (2, 3 and 4 cells per chain) and the values are below the zero line only for single cells and longer chains. According to $\mathrm{O}^{\prime}$ Connors et al. (1976) and Donaghay and Small (in prep.) values below zero indicate net removal by breaking of large chains into smaller ones and/or by ingestion, while those above zero represent net production of particles resulting from breakage of long chains.

In Chaetoceros pseudocurvisetus and Thalassiosira rotula it is apparent that only net removal occurred, whereas in Stephanopyxis palmeriana there was also net productior: The greatest removal occurred at or near the modal peaks (Fig, $4, a, b, c$ ). Donaghay and Small (in prep.) described an index of removal pressure on different size classes relative to the volume of algae present in this size class [(grazed-control)/con-
Choetoceros pseudocurvisetus
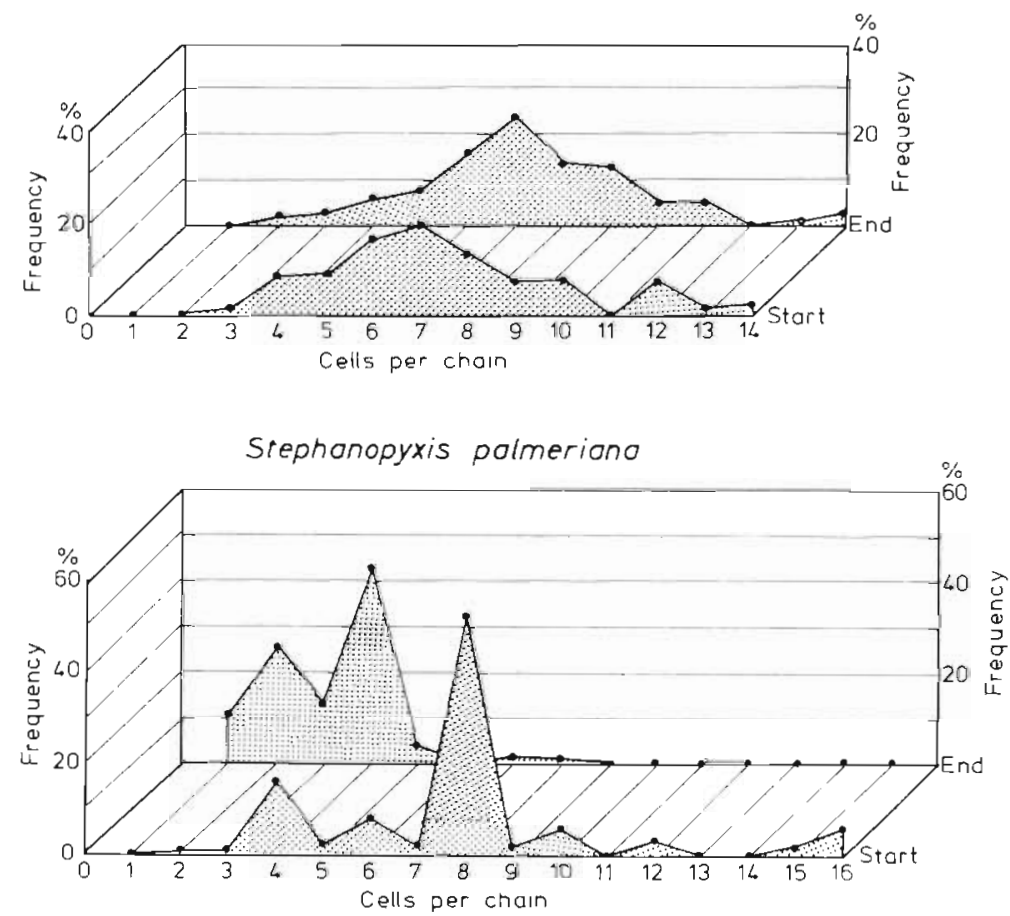

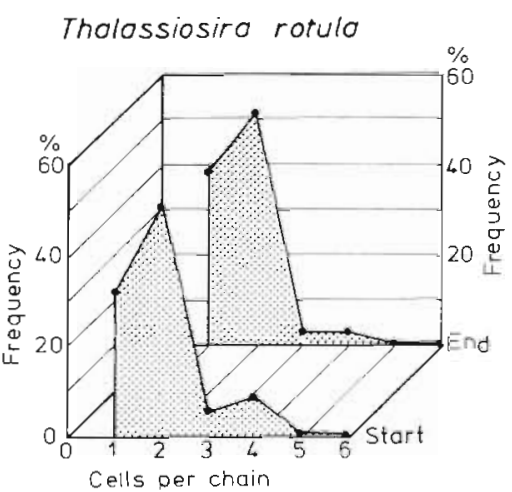

Fig. 3. Chain-length frequency of three diatom species at beginning and end of experiments 


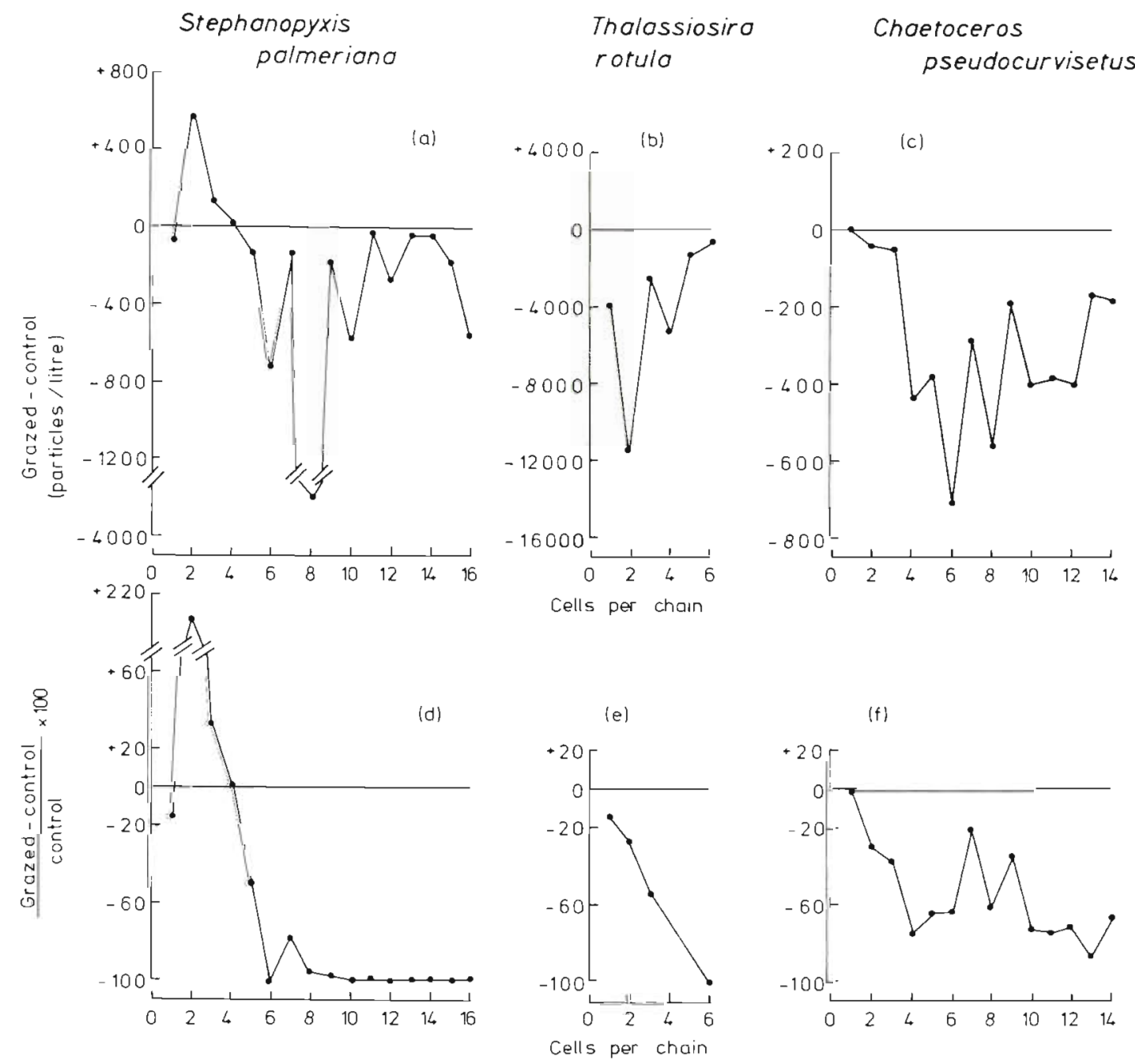

Fig. 4. Grazing effects on chain-length. Data presented as difference plots of grazed and control beakers (4a, b, c) and as indices of relative removal $(4 \mathrm{~d}, e, f)$

trol $\times 100$ ]: the more negative the index, the greater the removal pressure. Removal pressure was high on large chains of $S$. palmeriana with a steep decrease of the index between particle production and particle removal (Fig. 4d). For T. rotula a continuously increasing removal pressure was present as chains became longer (Fig. 4e). For C. pseudocurvisetus there was great variability in the removal pressure index (Fig. 4f). The index was low at the model peak ( 7 cells per chain), which is in contrast with the results obtained for $T$. rotula and $S$. palmeriana.

\section{DISCUSSION}

Several factors, such as shape, size, chemical composition and concentration of food particles can cause selective feeding by copepods. It is obvious from the results of the experiments presented in this paper that
Calanus helgolandicus did not feed preferentially on the most abundant species offered. Furthermore, $C$. helgolandicus grazed heavily in most experiments on the spiny Chaetoceros pseudocurvisetus. Different opinions concerning feeding on Chaetoceros occur in the literature. Harvey (1937), Parsons et al. (1967) and Hargrave and Geen (1970), for instance did not find feeding by copepods on Chaetoceros species. Their results contrast with those given in this study and by Raymont and Gross (1942), Marshall and Orr (1955), Paffenhöfer and Strickland (1970) and Heinle et al. (1976). In contrast to Thalassiosira rotula and Stephanopyxis palmeriana, the chains of C. pseudocurvisetus have a semicircular shape with a diameter of about $150 \mu \mathrm{m}$, which may contribute to the difference in how they are handled.

The mean-spherical diameter or cell volume of Chaeoceros pseudocurvisetus is less than that of Stephanopyxis palmeriana and Thalassiosira rotula 
Table 4. Mean length and chain volume of diatom species. For Chaetoceros the volume has been calculated (a) with spines and (b) without spines

\begin{tabular}{|lcccc|}
\hline Phytoplankton species & $\begin{array}{c}\text { Cells/ } \\
\text { chain }\end{array}$ & $\begin{array}{c}\text { Length/ } \\
\text { chain }(\mu \mathrm{m})\end{array}$ & $\begin{array}{c}\text { Chain } \\
\mathrm{a}\end{array}$ & $\begin{array}{c}\text { Volume }\left(\mu \mathrm{m}^{3}\right) \\
\mathrm{b}\end{array}$ \\
\hline Chaetoceros pseudocurvisetus & 7 & 105 & 15400 & 1071739 \\
Thalassiosira rotula & 2 & 46 & 45239 & - \\
Stephanopyxis palmeriana & 8 & 680 & 1081493 & - \\
\hline
\end{tabular}

(Table 1), but the C. pseudocurvisetus cells occupy a greater volume due to their long projecting spines. Table 4 gives the mean lengths and volumes of the chains for all the species; for $C$. pseudocurvisetus the value including spines is also given. From these data it is clear that the volume of $C$. pseudocurvisetus with spines is very close to that of $S$. palmeriana. The spines of $C$. pseudocurvisetus possibly increase the effective diameter of the chains and thus copepods would encounter $C$. pseudocurvisetus more often than expected if spines were not included in volume measurements. The evident preference for this species shown by Calanus helgolandicus could thus be explained by the larger volume occupied by it. Heinle et al. (1976) also found preferential feeding on Chaetoceros and proposed a similar explanation.

The importance of the size of the food organisms, independent of the species, was demonstrated by Mullin (1963). He found Calanus helgolandicus to feed preferentially on the larger chains of Asterionella japonica and larger cells of Rhizosolenia setigera. Martin (1970) reported that although Acartia clausi preferred Skeletonema costatum to the larger Rhizosolenia delicatula the larger chains of Skeletonema costatum were selected. When phytoplankton chains become Iong, the probability that a whole chain can be swallowed by a copepod decreases, and therefore the possibility of chain breakage increases. Breaking of long chains into smaller ones during grazing activity has been described by Parsons and Seki (1970), Paffenhöfer (1971, 1976), O'Connors et al. (1976), Donaghay and Small (in prep.). It is difficult to determine whether copepods filtered the larger chains in a suspension more efficiently and broke the chain during feeding or whether the larger chains were broken into smaller ones by the swimming activities of the copepods. The chains of Chaetoceros pseudocurvisetus and Thalassiosira rotula are much more fragile than those of Stephanopyxis palmeriana. Hence, $C$. helgolandicus is probably more likely to accidentally break longer chains in $T$. rotula and C. pseudocurvisetus than in S. palmeriana. Hence, true selective feeding on the longer chains of Stephanopyxis seems to be likely.

These experiments clearly show that female Calanus helgolandicus do not feed preferentially on the most abundant and suitable food organism, but select Chaetoceros pseudocurvisetus, whose spiny shape occupies a greater space. The results are particularly important because spiny forms such as Chaetoceros frequently dominate in the phytoplankton. More research on 'actual' and 'encounter' volumes is called for before we can deepen our understanding of trophic relationships in the pelagic ecosystem.

Acknowledgements. This study was supported by the Deutsche Forschungsgemeinschaft within the program 'Upwelling in the sea. Dr. H. K. Schöne provided the phytoplankton cultures. Drs. R. J. Conover, J. Lenz, G.-A. Paffenhöfer and V. Smetacek critically reviewed the manuscript and made many useful suggestions. I am most grateful for their help and advice.

\section{LITERATURE CITED}

Conover, R. J. (1978). Transformation of organic matter. In O Kinne (Ed.), Marine Ecology, Vol. IV, Dynamics. Wiley, Chichester. pp. 221-499.

Donaghay, P. L. and Small, L. F. (in prep.) Long-term food modification by Acartia clausi: A preliminary view.

Frost, B. W. (1972). Effects of size and concentration of food particles on the feeding behaviour of the marine planktonic copepod Calanus pacificus. Limnol. Oceanogr., 17. 805-815.

Gauld, D. T (1951). The grazing rate of planktonic copepods. J. mar. biol. Ass. U. K., 29, 695-706.

Hargrave, B T and Geen, G. H. (1970). Effects of copepod grazing on two natural phytoplankton populations. J. Fish. Res. Bd Can., 27, 1395-1403.

Harvey, H. W. (1937). Note on selective feeding by Calanus. J. mar. biol. Ass. U. K, 22, 97-100.

Heinle, D. R., Allan, J. D., Huff, R. T. and Richman, S. (1976). Seasonal interactions among estuarine primary producers and herbivores. Prog. Rep. ERDA Contract No. AT-(40-1)484 Ref. No. UMCEES 76-133 CBL.

Ivlev, V.S. (1961). Experimental Ecology of the Feeding of Fishes (transl. by D. Scott), Yale University Press, New Haven.

Kinne, O. (1977). Cultivation of animals: research cultivation. In O. Kinne (Ed.), Marine Ecology, Vol. III, Cultivation, Part 2. Wiley, London. pp, 579-1293.

Marshall, S. M. and Orr, A. P. (1955). On the biology of 
Calanus finmarchicus: Food uptake, assimilation and excretion in adult and stage V. J. mar. biol. Ass. U. K., 34 , 495-529.

Martin, J. H. (1970). Phytoplankton-zooplankton relationship in Narragansett Bay. IV The seasonal importance of grazing. Limnol. Oceanogr., 15, 413-418

Mullin, M. M. (1963). Some factors affecting the feeding of marine copepods of the genus Calanus. Limnol. Oceanogr. $8,239-250$.

O'Connors, H. B., Small, L. F. and Donaghay, P. L. (1976). Particle-size modification by two size classes of the estuarine copepod Acartia clausi. Limnol. Oceanogr., 21 300-308.

Paffenhöfer, G. A. (1971). Grazing and ingestion rates of nauplii, copepodids and adults of the marine planktonic copepod Calanus helgolandicus. Mar. Biol., 11, 286-298.

Paffenhöfer, G. A. (1976). Continuous and nocturnal feeding of the marine planktonic copepod Calanus helgolandicus. Bull. mar. Sci., 26, 49-58.

Paffenhöfer, G. A. and Strickland, J. D. H. (1970). A note on the feeding of Calanus helgolandicus on detritus. Mar Biol., 5, 97-99.

Parsons, T. R., LeBrasseur, R. J. and Fulton, J. D. (1967). Some observations on the dependence of zooplankton grazing on the cell size and concentration of phytoplankton blooms. J. oceanogr. Soc. Japan, 23, 10-17

Parsons, T. R. and Seki, H. (1970). Importance and general implications of organic matter in aquatic environments. In D. W. Hood (Ed.), Organic Matter in Natural Waters. Institute of Marine Science, University of Alaska. pp. 1-27.

Raymont, J. E. G. and Gross, F. (1942). On the feeding and breeding of Calanus finmarchicus under laboratory conditions. Proc. R. Soc. Edinb. B Sect., 61, 267-287.

Schnack, S. B. (1978). Feeding habits of Calanoides carinatus (Kroyer) in the NW-African upwelling region. In Symposium on the Canary Current: Upwelling and Living Resources, No. 75, 1-12.

Smetacek, V. (1975). Die Sukzession des Phytoplanktons in der Westlichen Kieler Bucht. Ph. D. thesis, Universität Kiel.

This paper was presented by Professor H.-P. Bulnheim; it was accepted for printing on May 30, 1979. 